\title{
PROFIL HAMBATAN BELAJAR EPISTIMOLOGIS SISWA PADA MATERI ASAS BERNOULLI KELAS XI SMA BERBASIS ANALISIS TES KEMAMPUAN RESPONDEN
}

\author{
Gita Wahyu Pebriyantia ${ }^{\text {a }}$, Harun Imansyah ${ }^{\text {b) }}$, A. F. C. Wijaya ${ }^{\mathrm{c}}$, Heni Rusnayatid \\ Departemen Pendidikan Fisika Fakultas Pendidikan Matematika dan Ilmu Pengetahuan Alam Universitas \\ Pendidikan Indonesia, Jl. Dr. Setiabudhi No. 229, Bandung 40154
}

Email: a)gitawahyup@yahoo.com, b)harun.imansyah@gmail.com, ${ }^{c}$ agus.fany@gmail.com, d)heni@upi.edu

\begin{abstract}
Abstrak
Berdasarkan hasil studi pendahuluan yang dilakukan peneliti melalui angket dan tes di salah satu SMAN di Kota Bandung menunjukkan bahwa lebih dari 50\% siswa mengalami hambatan belajar epistimologis pada materi fluida dinamis dan 66,22\% siswa tidak dapat mengerjakan tes pada materi Asas Bernoulli. Tujuan dari penelitian ini yaitu untuk mengidentifikasi profil hambatan belajar epistimologis siswa pada materi Asas Bernoulli kelas XI SMA berbasis analisis Tes Kemampuan Responden. Hambatan belajar epistimologis yaitu hambatan yang terjadi karena keterbatasan seseorang hanya pada suatu konteks tertentu dan akan mengalami hambatan untuk menggunakan pengetahuannya ketika dihadapkan pada konteks lain yang berbeda. Metode yang digunakan adalah deskriptif kualitatif dengan analisis pendekatan historis melalui Tes Kemampuan Responden berupa tiga soal uraian yang mencakup konsep esensial Asas Bernoulli yang diberikan kepada siswa di salah satu SMAN di Kota Bandung. Hasil ratarata dari masing-masing konsep esensial diperoleh $68,27 \%$ siswa mengalami hambatan belajar pada persamaaan Bernoulli dalam prinsip Torricelli, 95,36\% siswa mengalami hambatan belajar pada persamaan Bernoulli dalam prinsip Venturi, dan $87,05 \%$ siswa mengalami hambatan belajar pada persamaan Bernoulli dalam prinsip gaya angkat pesawat terbang. Jadi, penelitian ini dapat disimpulkan bahwa masih terdapat hambatan belajar epistimologis pada materi Asas Bernoulli, sehingga harus ada upaya untuk memperkecil hambatan belajarnya.
\end{abstract}

Kata-kata kunci: Hambatan Belajar, Asas Bernoulli, Tes Kemampuan Responden.

\begin{abstract}
Based on previous research through the questionnaire and test in one of the High School in Bandung, more than $50 \%$ of students experienced epistemological learning obstacles on the dynamic fluid material and $66,2 \%$ students couldn't answer the test about Bernoulli's principle. The aim of this study is to identify the student's epistemological learning obstacles profile of grade XI Bernoulli's principle material, based on the respondent's ability test. Epistemological learning obstacles occur due to limitation of knowledge to a certain concept and it will lead to obstacles in using their knowledge when facing different concept. The method is qualitative descriptive, combined with the historical approach analysis through the respondent's ability test in the form of three essays covering essential concepts of Bernoulli's principle, which given to the students in one of the High School in Bandung. The average score $68,27 \%$ is the students who experienced obstacles about Bernoulli's equation in Torricelli's principle, 95,36\% is the students facing obstacles about Bernoulli’s equation in Venturi’s principle, and
\end{abstract}


$87,05 \%$ the students obstacles on Bernoulli's principle in aircraft lift force. The conclusion is the encounter of epistemological learning obstacles on Bernoulli's principle material, there must be effort to minimize learning obstacles.

Keywords: Learning obstacles, Bernoulli’s principle, Respondent’s Ability Test.

\section{PENDAHULUAN}

Menurut Undang-Undang Republik Indonesia No. 20 Tahun 2003 tentang sistem pendidikan nasional, pendidikan adalah usaha sadar dan terencana untuk mewujudkan suasana belajar dan proses pembelajaran agar peserta didik secara aktif mengembangkan potensi dirinya untuk memiliki kekuatan spiritual keagamaan, pengendalian diri, kepribadian, kecerdasan, akhlak mulia, serta keterampilan yang diperlukan dirinya, masyarakat, bangsa dan negara. Mengacu pada UndangUndang tersebut maka dapat dikatakan bahwa pendidikan merupakan suatu hal utama untuk membentuk sebuah fondasi kepribadian manusia. Salah satu cabang ilmu pengetahuan dalam dunia pendidikan adalah sains. Bagian dari sains yang mempelajari fenomena dan gejala alam secara empiris, logis, sistematis dan rasional yang melibatkan proses dan sikap ilmiah yaitu fisika. Belajar fisika dapat mengenalkan mengenai produk fisika berupa materi, konsep, asas, teori, prinsip dan hukum-hukum fisika.

Fisika merupakan ilmu yang melekat dengan kehidupan sehari-hari karena materi yang dipelajarinya sangat erat kaitannya dengan fenomena-fenomena yang terjadi. Walaupun demikian, tidak banyak orang mengatakan bahwa fisika itu mudah. Bahkan banyak siswa yang mengatakan bahwa fisika itu menyeramkan karena berputar dengan rumus dan memerlukan daya ingat yang kuat untuk menganalisis dalam penggunaan rumusnya. Menurut (Robia Astuti, 2017) dalam usaha penguasaan suatu materi pembelajaran terdapat banyak unsur secara bersama-sama mempengaruhi keberhasilannya antara lain siswa, guru, metode pembelajaran yang digunakan serta lingkungan yang ada. Jika ditinjau dari siswa, faktor yang mempengaruhi prestasi belajar siswa dapat dikelompokkan menjadi dua golongan yaitu : faktor internal dan faktor eksternal. Faktor internal merupakan salah satu penyebab rendahnya hasil belajar siswa yang ditunjukkan dengan siswa tidak mampu mengerjakan soal dan terjadi kesalahan-kesalahan dalam pengerjaannya. Ketidakmampuan tersebut menunjukkan siswa mengalami suatu hambatan belajar.

Hambatan belajar (learning obstacle) adalah suatu kondisi dimana seseorang tidak dapat mengkuti proses belajar dengan baik yang ditandai dengan adanya hambatan-hambatan tertentu dalam mencapai hasil belajar. Menurut Brousseau (2002) hambatan belajar dibagi berdasarkan sistem (guru-siswa-materi) menjadi tiga yaitu hambatan ontogeni (faktor kesiapan mental), hambatan didaktis (faktor transfer ilmu dari guru ke siswa), dan hambatan epistimologis (keterbatasan pengetahuan siswa pada konteks tertentu).

Ketiga hambatan tersebut akan dibahas lebih lanjut, faktor penyebab munculnya hambatan belajar menurut Brousseau (2002) sebagai berikut;

- Hambatan Ontogeni

Hambatan Ontogeni adalah hambatan terkait ketidaksiapan mental belajar siswa karena perkembangan mental dan kognitif yang jauh tertinggal dengan perkembangan biologisnya. Salah satu penyebabnya yaitu pembatasan konsep pembelajaran pada saat perkembangan anak.

- Hambatan Didaktis

Hambatan Didaktis adalah hambatan terkait kekeliruan proses pembelajaran di sekolah itu sendiri. Salah satu penyebabnya yaitu cara guru membuat atau merancang pembelajaran kurang tepat atau kesalahan dari sumber belajar siswa. Misalnya menggunakan analogi yang kurang tepat sehingga pengetahuan yang disampaikan memungkinkan dimaknai berbeda oleh siswa.

- Hambatan Epistimologis

Hambatan Epistimologis adalah hambatan terkait pengetahuan siswa terhadap suatu konten. Salah satu penyebabnya yaitu keterbatasan pengetahuan yang dimiliki seeorang hanya pada suatu konteks tertentu atau pemahaman sebuah konsep yang tidak lengkap. Jika dihadapkan pada konteks lain yang berbeda, maka akan mengalami hambatan untuk menggunakan pengetahuan tersebut. 
Pada kenyataannya, hambatan belajar siswa dapat dilihat dari hasil studi pendahuluan yang telah dilakukan peneliti melalui angket dan tes di salah satu SMA di Kota Bandung. Melalui angket yang diberikan kepada siswa hasil yang diperoleh yaitu 60,53\% siswa mengalami hambatan belajar dalam mempelajari fluida dinamis terutama Asas Bernoulli. Salah satu penyebab terjadinya hambatan belajar siswa yaitu keterbatasan siswa dalam memahami suatu konsep karena pemahamannya yang tidak lengkap atau utuh berkisar lebih dari 50\% yang disebut sebagai hambatan epistimologis. Selain itu, hambatan dapat dilihat dari hasil tes yang menunjukkan bahwa sekitar 66,22\% siswa tidak dapat mengerjakan tes pada materi Asas Bernoulli. Berdasarkan studi pendahuluan tersebut peneliti bertujuan untuk mengidentifikasi profil hambatan belajar epistimologis siswa kelas XI SMA pada materi Asas Bernoulli berdasarkan analisis Tes Kemampuan Responden (TKR). Dalam buku yang berjudul Theory of Didactical Situation, Brousseau (2002, hal 101) hambatan epistimologis dapat dilihat melalui analisis pendekatan historis siswa dalam :

1. Menjelaskan dan memahami pengetahuan yang dipelajari

2. Memahami penggunaan pengetahuan yang mereka pelajari

3. Melihat hubungan antara konsep yang dipelajari dengan konsep-konsep lain yang berhubungan

4. Mengidentifikasi permasalahan dan menjelaskan alasan atas penyelesaian yang diberikan

5. Mengulangi jawaban yang salah pada permasalahan yang sama, serta cara masing-masing siwa memahami permasalahan.

\section{METODE PENELITIAN}

Penelitian ini menggunakan metode deskriptif kualitatif dengan analisis pendekatan historis yang merupakan ungkapan dari buku Theory of Didactical Situation, Brosseau (2002, hal 101) dengan menggunakan Tes Kemampuan Responden (TKR) berupa tes uraian yang terdiri atas tes tertulis sebanyak 3 (tiga) soal yang mencakup konsep esensial dari materi Asas Bernoulli. Soal berbentuk essay ini bertujuan supaya tergambar pola pikir mereka dalam menjawab soal serta jawaban yang dipilih merupakan hasil pemikiran terlebih dahulu. TKR diberikan pada siswa yang telah mempelajari materi Asas Bernoulli. Sebelum dilaksanakan TKR, instrumen dilakukan validasi terlebih dahulu melalui judgement guru dan dosen pembimbing. Subjek penelitian ini yaitu siswa yang telah mempelajari materi Asas Bernoulli di salah satu SMA Negeri di Kota Bandung yang berjumlah 34 orang.

\section{HASIL DAN PEMBAHASAN}

Dari hasil penelitian yang dilakukan terdapat hambatan epistimologis siswa pada konsep-konsep esensial materi Asas Bernoulli melalui Tes Kemampuan Responden (TKR) dengan uraian sebagai berikut;

\section{A. Prinsip Torricelli}

TABEL 1. Hambatan Belajar pada persamaaan Bernoulli dalam prinsip Torricelli atau lubang Kebocoran

\begin{tabular}{clc}
\hline Coding & \multicolumn{1}{c}{ Keterangan } & Persentase TKR \\
\hline 1 & $\begin{array}{l}\text { Tidak dapat menentukan nilai besaran yang ditanyakan dalam } \\
\text { soal pada prinsip Torricelli atau lubang kebocoran }\end{array}$ & $51,25 \%$ \\
2 & $\begin{array}{l}\text { Tidak dapat menjelaskan prinsip Bernoulli pada tangki } \\
\text { berlubang Torricelli }\end{array}$ & $85,29 \%$ \\
\hline
\end{tabular}


Tabel 1 menunjukkan hambatan terbesar yaitu 85,29\% siswa tidak dapat menjelaskan prinsip Bernoulli pada tangki berlubang Torricelli. Apabila kedua coding dari tabel tersebut dirata-ratakan maka sebesar 68,27\% siswa mengalami hambatan belajar pada persamaaan Bernoulli dalam prinsip Torricelli atau lubang Kebocoran. Kedua coding dapat dilihat melalui soal dan contoh jawaban siswa pada soal nomor 1 kasus tangki berlubang Torricelli dalam bentuk gambar.

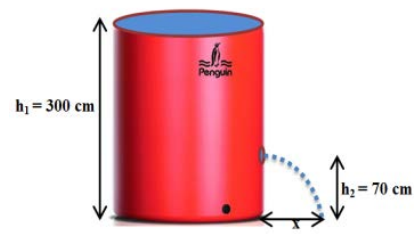

GAMBAR 1. Gambar soal tangki berlubang Torricelli

Gambar 1 diambil dari soal nomor 1 siswa diminta untuk menentukan nilai besaran kecepatan dan jarak serta menjelaskan prinsip Bernoulli pada tangki berlubang Torricelli.

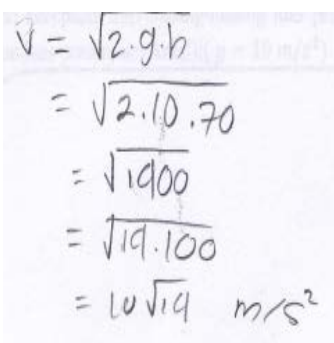

GAMBAR 2. Contoh jawaban siswa pada soal nomor 1 untuk coding 1 Torricelli

Gambar 2 diambil sebagai contoh hambatan yang terjadi pada prinsip Torricelli coding 1 yakni siswa tidak dapat menentukan nilai besaran yang ditanyakan dalam soal pada jawabannya terlihat siswa menggunakan besaran ketinggian (h) yang keliru karena memasukkan nilai 70 dengan asumsi ketinggian $\left(h_{2}\right)$ dari lubang kebocoran hingga tanah dan tidak mengkonversi satuan yaitu dari $\mathrm{cm}$ ke $m$. Seharusnya dalam kasus teorema Torricelli ketinggian $\left(h_{1}-h_{2}\right)$ yang dimaksud yaitu dari permukaan air hingga lubang kebocoran. Selain itu, satuan yang digunakan siswa dalam besaran kecepatan (v) yakni $m / s^{2}$. Seharusnya satuan untuk kecepatan adalah $m / s$. Dari analisis jawaban tersebut siswa tidak dapat memahami besaran dan satuan yang ditanyakan pada soal prinsip Torricelli yang menunjukkan bahwa siswa tersebut mengalami hambatan belajar.

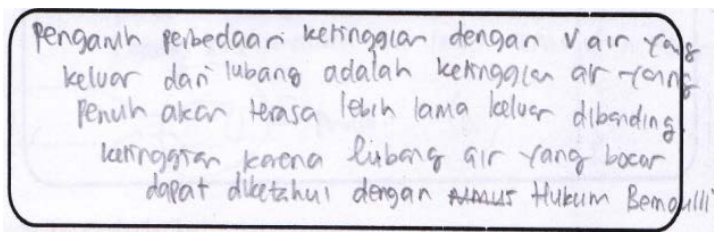

GAMBAR 3. Contoh jawaban siswa pada soal nomor 1 untuk coding 2 Torricelli

Gambar 3 diambil sebagai contoh hambatan yang terjadi pada Torricelli coding 2 yakni siswa tidak dapat menjelaskan konsep Bernoulli pada tangki berlubang Torricelli pada jawabannya siswa menyatakan bahwa perbedaan ketinggian (h) dengan kecepatan (v) akan terasa lebih lama artinya kecepatannya kecil. Sementara pada kasus ini semakin besar perbedaan ketinggian atau ketinggian yang dimaksud adalah tinggi dari permukaan air hingga ke lubang semakin besar maka kecepatan air 
yang keluar pun akan besar, sebenarnya siswa dapat mengasumsikannya dari persamaan ataupun dari hasil yang didapat dari pertanyaan sebelumnya mengenai kecepatan air yang keluar dari tangki kebocoran yaitu $v=\sqrt{2 g h}$.

\section{B. Prinsip Efek Venturi}

TABEL 2. Hambatan belajar pada persamaan Bernoulli dalam prinsip Venturi

\begin{tabular}{clc}
\hline Coding & \multicolumn{1}{c}{ Keterangan } & Persentase TKR \\
\hline 1 & $\begin{array}{l}\text { Tidak dapat menentukan nilai besaran yang ditanyakan dalam } \\
\text { soal pada kasus venturimeter }\end{array}$ & $93,62 \%$ \\
2 & Tidak dapat menjelaskan prinsip Bernoulli pada efek Venturi & $97,11 \%$ \\
\hline
\end{tabular}

Tabel 2 menunjukkan hambatan terbesar yaitu 97,11\% siswa tidak dapat menjelaskan prinsip Bernoulli pada efek Venturi. Apabila kedua coding dari tabel tersebut dirata-ratakan maka sebesar 95,36\% siswa mengalami hambatan belajar pada persamaan Bernoulli dalam prinsip Venturi.

Kedua coding dapat dilihat melalui soal dan contoh jawaban siswa pada soal nomor 2 kasus Venturi dalam bentuk gambar

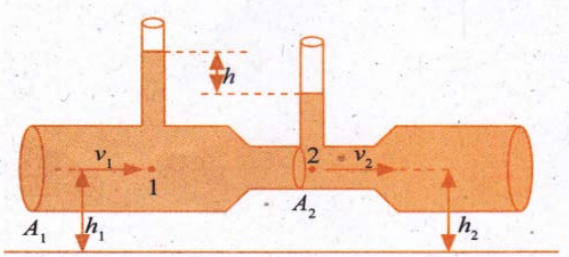

GAMBAR 4. Gambar soal Venturimeter tanpa manometer

Gambar 4 diambil dari soal nomor 2 siswa diminta untuk menentukan nilai besaran kecepatan pada masing-masing luas penampang yang berbeda di titik 1 dan titik 2 serta menjelaskan prinsip Bernoulli pada venturimeter tanpa manometer.

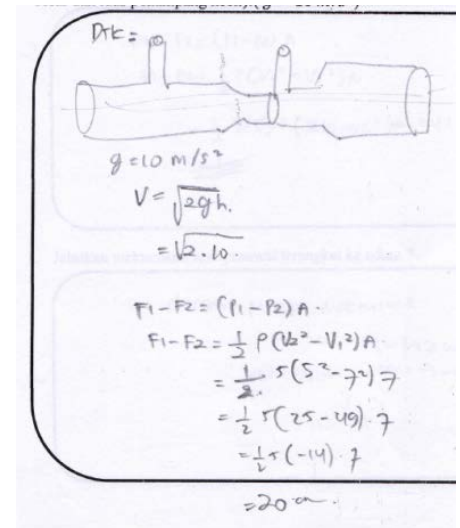

GAMBAR 5. Contoh jawaban siswa pada soal nomor 2 untuk coding 1 Venturi

Gambar 5 diambil sebagai contoh hambatan yang terjadi pada Venturi coding 1 yakni siswa tidak dapat menentukan nilai besaran yang ditanyakan dalam soal, pada jawabannya siswa menggunakan 
persamaan Bernoulli yang tidak sesuai. Seharusnya pada kasus venturimeter tanpa manometer persamaannya yaitu

$$
v_{1}=\sqrt{\frac{2 g h}{\left(\frac{A_{1}}{a_{2}}\right)^{2}-1}} \text { dan } v_{2}=\sqrt{\frac{2 g h}{1-\left(\frac{A_{2}}{a_{1}}\right)^{2}}} \text { Sehingga hasil yang didapatnya pun salah. Dalam efek Venturi }
$$

tepatnya kasus venturimeter tanpa manometer persamaan ataupun konsepnya berkaitan dengan persamaan Kontinuitas yang telah dipelajari sebelumnya, artinya siswa tidak dapat mengaitkan konsep lain serta pengetahuan yang dimilikinya tidak utuh sehingga ketika dihadapkan dengan konteks yang berbeda siswa tidak mampu menghadapinya.

$$
\text { Sama sama saja karna pumusnya sama }
$$

GAMBAR 6. Contoh jawaban siswa pada soal nomor 2 untuk coding 2 Venturi

Gambar 6 diambil sebagai contoh hambatan yang terjadi pada Venturi coding 2 yakni siswa tidak dapat menjelaskan prinsip Bernoulli pada efek Venturi. Siswa masih menganggap bahwa kecepatan dengan luas penampang yang berbeda adalah sama. Seharusnya ketika luas penampangnya besar maka kecepatannya akan kecil begitupun sebaliknya.

\section{Persamaan Bernoulli dalam prinsip gaya angkat pesawat terbang}

TABEL 3. Hambatan belajar pada persamaan Bernoulli dalam prinsip gaya angkat pesawat terbang

\begin{tabular}{ccc}
\hline Coding & Keterangan & Persentase TKR \\
\hline & $\begin{array}{c}\text { Tidak dapat menentukan nilai besaran yang ditanyakan dalam } \\
\text { soal pada kasus sayap pesawat terbang }\end{array}$ & $91,75 \%$ \\
& Tidak dapat menjelaskan konsep Bernoulli pada gaya angkat \\
& pesawat terbang & $82,35 \%$ \\
\hline
\end{tabular}

Tabel 3 menunjukkan hambatan terbesar yaitu 91,75\% siswa tidak dapat menentukan nilai besaran yang ditanyakan dalam soal pada kasus sayap pesawat terbang. Apabila kedua coding dari tabel tersebut dirata-ratakan maka sebesar $87,05 \%$ siswa mengalami hambatan belajar pada persamaan Bernoulli dalam prinsip gaya angkat pesawat terbang.

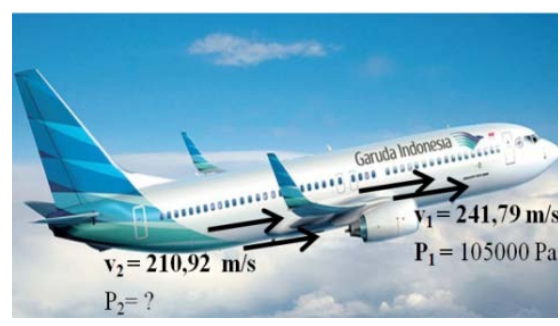

GAMBAR 7. Gambar soal pesawat terbang

Gambar 7 diambil dari soal nomor 3 siswa diminta untuk menentukan nilai besaran tekanan pesawat terbang serta menjelaskan prinsip Bernoulli pada mekanisme gaya angkat sayap pesawat terbang. 


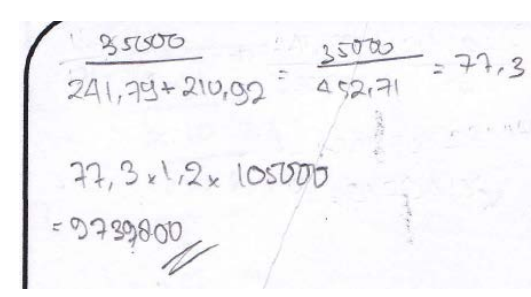

GAMBAR 8. Contoh jawaban siswa pada soal nomor 3 untuk coding 1 sayap pesawat terbang

Gambar 8 diambil sebagai contoh hambatan yang terjadi pada Venturi coding 1 yakni siswa tidak dapat menentukan nilai besaran yang ditanyakan dalam soal pada kasus sayap pesawat terbang, jawaban siswa hanya menghitung sesukanya serta tidak sesuai dengan persamaan Bernoulli pada sayap pesawat pada umumnya yaitu $P_{2}=P_{1}+\frac{1}{2} \rho\left(v_{1}^{2}-v_{2}^{2}\right)$.

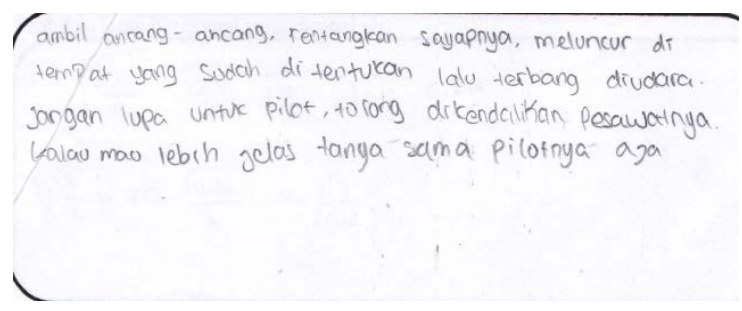

GAMBAR 9. Contoh jawaban siswa pada soal nomor 3 untuk coding 2 sayap pesawat terbang

Gambar 9 diambil sebagai contoh hambatan yang terjadi pada Venturi coding 2 yakni siswa tidak dapat menjelaskan konsep Bernoulli pada gaya angkat pesawat terbang, pada jawabannya siswa justru menjelaskan dengan tidak serius serta tidak ada konsep fisikanya sama sekali. Seharusnya siswa menjelaskan mekanisme gaya angkat pesawat melalui Asas Bernoulli yaitu kecepatan diatas sayap lebih besar dibandingkan dengan kecepatan sayap bawah sehingga tekanan diatas sayap lebih kecil dan tekanan dibawah lebih besar. Terjadi hubungan kecepatan dengan tekanan yang berbanding terbalik, karena adanya perbedaan tekanan di atas dengan di bawahlah yang menyebabkan pesawat tersebut bisa naik.

\section{SIMPULAN}

Berdasarkan data dan hasil pembahasan diperoleh kesimpulan bahwa profil hambatan belajar epistimologis siswa dapat terlihat dari hasil analisis Tes Kemampuan Responden (TKR) yang menunjukkan 68,27 \% siswa mengalami hambatan belajar pada persamaaan Bernoulli dalam prinsip Torricelli atau lubang Kebocoran, 95,36 \% siswa mengalami hambatan belajar pada persamaan Bernoulli dalam prinsip Venturi, dan 87,05 \% siswa mengalami hambatan belajar pada persamaan Bernoulli dalam prinsip gaya angkat pesawat terbang. Sehingga harus ada upaya untuk memperkecil hambatan belajarnya.

\section{REFERENSI}

[1] Astuti, Robia. Analisis Learning Obstacles Mahasiswa dalam mempelajari materi Kombinatorial. Pendidikan Matematika, STKIP Muhammadiyah Pringsewu Lampung. Jurnal Edumath, Volume 3 No. 1. 2017.

[2] Brousseau, G. Theory of Didactical Simulations in Mathematics. New York: Kluwer Academic Publisher, 2002.

[3] Nusantara, Fauzan. Desain Didaktis Konsep Usaha kelas XI SMA Berdasarkan Analisis Kesulitan Belajar Siswa. Skripsi, Universitas Pendidikan Indonesia. 2015 
[4] Pebriani, Evi. Desain Didaktis materi Penjumlahan Vektor Berdasarkan Hambatan Belajar pada Siswa SMA kelas X. Skripsi, Universitas Pendidikan Indonesia. 2016

[5] Pemerintah Republik Indonesia.Undang-Undang Republik Indonesia No. 20 Tahun 2003 tentang Sistem Pendidikan Nasional. Jakarta. 2003.

[6] Utari, Silvia. Desain didaktis berbantuan lesson analysis sebagai refleksi diri guru dalam pembelajaran kimia SMA kelas XI pada konsep jenis-jenis dan sifat-sifat koloid. Tesis, Universitas Pendidikan Indonesia. 2014. 